\title{
Nutritional assessment and disease activity for patients with inflammatory bowel disease
}

\author{
Thomas E Wasser med, James F Reed PhD, KathleEn Moser BA, PAmela Robson, Linda Faust ms, \\ LORI L FINK BA, DENISE WUNDERLER BS
}

TE WASSER, JF REED, K MOSER, et al. Nutritional assessment and disease activity for patients with inflammatory bowel disease. Can J Gastroenterol 1995;9(3):131-136. Using the Harvard/Willett Semi-Quantitative Food Frequency Questionnaire (H/WSQFFQ), nutritional information was gathered on patients enrolled in an inflammatory bowel disease (IBD) registry. The registry lists 320 patients positive for either ulcerative colitis $(n=124)$ or Crohn's disease $(\mathrm{n}=196)$. The sample was limited to those 19 to 84 years old (mean \pm SD 48.57 \pm 14.98 ), and comprised 136 males and 184 females. Using a battery of indices, quality of life, disease activity and general well-being were also assessed. $\mathrm{Nu}$ tritional intake values from the Harvard-Willett data were compared with recommended dietary allowances (RDA) tables by sex and age group (19 to 24 years, 25 to 50, 51 and older) to discover any intake deficiencies. Results showed that IBD patients were below RDA guidelines for vitamin E, calcium, magnesium, zinc, iodine and selenium. Females were below RDA guidelines for iron while men were below for vitamin $\mathrm{B}_{6}$. There were also some deficiencies according to age in males and two nutrient deficiencies were seen by age group in women. There were no deficiencies by sex or age for vitamins A, C, D and niacin. There were no observed nutrient intake differences between ulcerative colitis and Crohn's disease groups. Patients receiving vitamin or mineral supplementation showed significant decreases in quality of life, regardless of diagnosis (Crohn's disease or ulcerative colitis) group. The H/WSQFFQ is a useful tool for assessment of the nutritional status of the IBD patient because it not only provides valuable measurement data to the clinician, but also adds to patient awareness about nutritional problems associated with IBD.

Key Words: Inflammatory bowel disease, Nutrient intake, Nutrition

\section{Évaluation nutritionnelle et évolution des patients atteints de maladies inflammatoires de l'intestin}

RÉSUMÉ : À l'aide du questionnaire H/WSQFFQ (Harvard/Willett SemiQuantitative Food Frequency Questionnaire), des renseignements d'ordre nutritionnel ont été recueillis auprès de patients inscrits à un registre des maladies in-

voir page suivante

The Research Department, The Lehigh Valley Hospital, Allentown, Pennsylvania, USA Correspondence and reprints: Dr Thomas E Wasser, Research Department, The Lehigh Valley Hospital, Cedar Crest Ë I-78, PO Box 689, Allentown, PA 18105-1556, USA. Telephone (610) 402-8889, Fax (610) 402-1282, e-mail thomas.wasser@lvhgate.lvh.com Received for publication July 21, 1994. Accepted November 21, 1994
$M$ ALNUTRITION IN PATIENTS suffering from inflammatory bowel disease (IBD) is a common and often cited characteristic of the disease (1-2). Driscoll and Rosenberg (3) reported that the four primary causes of malnutrition in IBD patients are decreased oral intake, increased nutritional requirements, malabsorption and gastrointestinal loss. We focused on intake levels and how they relate to quality of life and disease activity in these patients.

The emphasis of most nutritional research in IBD is the examination of which type of diet, primarily elemental or parenteral nutrition, is most effective in allowing patients to tolerate the symptoms of their disease (4-6). Some studies have examined nutritional support, bowel rest and dietary factors, and how they affect the remission of symptoms, hospital admissions, days spent in the hospital for treatment or relapse. Cravo et al (7) assessed serum albumin levels of Crohn's disease patients on both admission and discharge. However, no studies have examined the effects of total dietary intake on the overall well-being of the IBD patient.

This study combined the Harvard/ Willett Semi-Quantitative Food Frequency Questionnaire (H/WSQFFQ) with several indices to compare patient nutrition intake with quality of life and disease activity. In addition to having determined the nutritional intake 
flammatoires de l'intestin (MII). Le registre compte 320 patients porteurs de diagnostics de colite ulcéreuse $(\mathrm{n}=124)$ ou de maladie de Crohn $(\mathrm{n}=196)$. L'échantillon a été limité aux patients âgés de 19 à 84 ans (moyenne \pm écart type $48,57 \pm 14,98$ ) et était composé de 136 hommes et 184 femmes. À l'aide d'une batterie d'indices, la qualité de vie, l'activité de la maladie et l'état général de bienêtre ont également été évalués. L'apport nutritionnel tiré des données HarvardWillett a été comparé avec l'apport alimentaire recommandé selon le sexe et l'âge (19 à 24 ans, 25 à 50 ans, 51 ans et plus) afin de déceler tout déficit nutritionnel. Les résultats ont révélé que les patients atteints de MII se situaient sous la normale à l'égard de la vitamine $\mathrm{E}$, du calcium, du magnésium, du zinc, de l'iode et du sélénium. Les femmes se trouvaient sous la normale pour le fer, alors que les hommes se trouvaient sous la normale pour la vitamine $\mathrm{B}_{6}$. Certains déficits liés à l'âge ont aussi été notés chez les hommes et deux déficits nutritionnels ont été notés par groupe d'âge chez les femmes. Aucune déficience nutritionnelle n'a été identifiée selon le sexe ou l'âge pour ce qui est des vitamines A, C, D et de la niacine. Aucune différence n'a été notée quant à l'apport en éléments nutritifs entre les groupes atteints de colite ulcéreuse et de maladie de Crohn. Les patients qui recevaient des suppléments vitaminiques ou minéraux manifestaient une meilleure qualité de vie, sans égard au diagnostic (maladie de Crohn ou colite ulcéreuse). Le H/WSQFFQ a été un outil d'évaluation utile du statut nutritionnel des patients atteints de MII parce qu'il ne procure pas que des données valables aux cliniciens mais ajoute également à la sensibilisation du patient à l'égard des problèmes nutritionnels associés aux MII.

status of IBD patients overall, ulcerative colitis and Crohn's disease groups were compared for any intake differences, with intake levels also compared with recommended dietary allowance (RDA) levels according to sex and age groups. We also conducted a chart review for blood levels of nutrients in the same patients. Although limited for purposes of interpretation, these data are of interest to researchers in nutrient serum and intake levels.

\section{PATIENTS AND METHODS}

An existing IBD registry, reported by Reed et al (8) in 1992, was used to recontact patients, soliciting their cooperation in this study. Patients were mailed a participant information letter to inform them that they would be contacted by telephone. Reprints of an article entitled 'An analysis of Crohn's disease activity indices from a registry of patients in eastern Pennsylvania', published in this Journal, were included in the mailing (9). This was one of the articles that resulted from telephone interviews conducted from Spring 1989 through Fall 1989.

Members of the registry aged 16 years or older were selected as participants for this study. Study sample size, after excluding those outside the age range, those who had died and those unable to be contacted by telephone and mail, was anticipated to be 363 . A total of 320 registry members $(88.15 \%)$ were interviewed (136 males and 184 females).

In order to assess health-related quality of life, several tools were examined. Based on previous experiences with indices, the Modified Organisation Mondiale de Gastroentérologie (OMGE) Index was selected for assessment of disease activity because of its ease of calculation and simplicity. A general health survey, the IBD Symptom Questionnaire (ISQ), was also chosen; each item in the questionnaire is rated using a Likert scale from 'not very important' to 'extremely important'. The ISQ has been used in a study including 97 patients with IBD. The Quality of Life Index (QLI), which has been used by physicians to measure the quality of life in cancer patients and patients with a definite chronic disease, was also selected. Thus, a linear combination of these three tools - OMGE, ISQ and QLI - was employed.

The H/WSQFFQ was selected for dietary assessment because it allows detailed analysis of the patient nutritional assessment form (10). This questionnaire was developed over 12 years of continuous evaluation, refinement and re-evaluation, and had been originally intended for use as a selfadministered mailed questionnaire in a nurses' health study (11). Results of validation studies among adults of all ages and both sexes have proven the tool to be remarkably robust (10-15). It has been used in more than 100 other studies and its widespread use has helped define its scope as a methodology and its degree of validation. Participants in these studies have included low-income pregnant women, preschool children, male health professionals, medical students, graduate students in public health nutrition, patients with coronary artery disease and hypercholesterolemia, and patients with carotid atherosclerosis.

The H/WSQFFQ consists of 61 items and was designed to assess the dietary intake of a variety of nutrients hypothesized to be associated with cancer or heart disease. These include protein, specific types of fat, cholesterol, total carbohydrates, sucrose, crude and dietary fibre, preformed and provitamin $\mathrm{A}$, and vitamins $\mathrm{E}, \mathrm{C}$ and $\mathrm{B}_{6}$. In addition to frequency intake, a nutrient and calorie intake may be computed for each subject and food category by multiplying the nutrient value for the specified portion size by a weight proportional to the frequency of each food and by summing the contribution of all foods.

The food groups include: dairy products, fruits, vegetables, meats, sweets and baked goods, breads, cereals, starches, carbonated beverages (diet and regular), other beverages and a miscellaneous category. Each food group is further subdivided. For example, the dairy category contains line items such as skim or low fat milk, cream, nondairy coffee creamer, sherbet or ice milk, ice cream, yoghurt, cottage or ricotta cheese, other cheeses, margarine and butter. The other groups are divided in similar detail.

In addition, the H/WSQFFQ provides intake levels for nutrients with and without vitamin pill supplementation. These include minerals (calcium, iron, zinc and selenium), fat-soluble vitamins (vitamins $\mathrm{A}, \mathrm{D}$ and $\mathrm{E}$ ) and 
water-soluble vitamins (vitamins $\mathrm{C}$, $\mathrm{B}_{6}, \mathrm{~B}_{12}$, thiamin, riboflavin and folate). Supplementation information provided by this questionnaire did not differentiate between pharmacological and megadose information; only intake levels with and without supplementation were provided.

Several meetings were held with the interview conductors to identify problems and estimate time requirements, and to acquaint the interviewers with the forms, the interview process, and the correct and consistent methods for completion of the forms, particularly the Willett questionnaire.

Interviews were conducted by telephone from February 24, 1992 through April 22, 1992. Though interview times varied, the average time needed to complete the assessments was 35 mins/patient. Some patients found the telephone interview to be inconvenient or uncomfortable and, as a result, requested that the data forms be mailed to them for completion at home. The research team tried to accommodate everyone. Responses to these mailed forms were encouraging and 51 completed forms were returned. The data were carefully checked, and if there were any incomplete or questionable areas of information, the forms were returned to the patient or the patient was contacted by telephone for clarifications. Information from forms returned by mail was transferred to the actual form to ensure consistency and facilitate machine processing of results. The forms were then coded according to the questionnaire manual. Forms were reviewed once more before processing to ensure that each form was thoroughly completed. On May 1, 1992 the forms were sent to the Senior Research Dietitian in charge of communication and processing for users at Harvard Medical School.

The authors also conducted a retrospective chart review of registry members to abstract blood level information for as many dietary factors as possible. Although the authors are aware of the many factors that can affect nutrient levels in an IBD patient, they were interested in blood nutrient levels as an available assessment. Records dated

TABLE 1

Institutional methodology for laboratory values

\begin{tabular}{|c|c|c|}
\hline Nutrients & Instrumentation & Methodology \\
\hline $\begin{array}{l}\text { Calcium, phosphorous, } \\
\text { magnesium, potassium, total } \\
\text { protein and sodium }\end{array}$ & $\begin{array}{l}\text { Technicon DAX } 48 \\
\text { (New York) }\end{array}$ & Photometric \\
\hline Iron & $\begin{array}{l}\text { DuPont Dimension ES } \\
\text { (Delaware) }\end{array}$ & Photometric \\
\hline Zinc and copper & Sent to outside facility & Atomic absorption \\
\hline Vitamin $B_{12}$ & $\begin{array}{l}\text { Abbott Gamma Counter } \\
\text { (Illinois) }\end{array}$ & Radioimmunoassay \\
\hline
\end{tabular}

nearest patient completion of the nutritional questionnaire were used for this review. These charts were also reviewed to determine if nutritional consultations were ordered for patients who were being actively treated for their disease. Blood serum levels for 130 of 320 registry patients (40.6\%) were obtained and entered onto data sheets for the following nutrients: calcium, cholesterol, protein, sodium, vitamin $B_{12}$, zinc, carotene, copper, iron, magnesium, phosphorous and potassium. The laboratory values used were determined as outlined in Table 1. Although methodological difficulties with the data involved using this convenience sample were apparent, the authors felt that relevant information could be obtained by examining any associations between intake and blood levels.

\section{DATA ANALYSIS}

Upon receipt of the tabulated nutritional assessment data from Harvard, the data were inspected for accuracy and examined for violations of normality. Disease activity data were entered into a microcomputer system where they could be joined with the nutritional data. Nutritional intake levels for all registry patients were assessed according to the Food and Nutrition Board, National Academy of Sciences-National Research Council RDA grouping categories for sex and age (16). Patients were divided into at, above or below minimum intake groups depending upon their H/WSQFFQ total compared with the minimum RDA requirement for each nutrient. $\chi^{2}$ and $t$ test analyses were used to examine adequate and nonadequate nutrient intake levels against the disease activity scales. Subscales of both the OMGE and QLI were further analyzed by nutrient intake to discover whether differences existed. These comparisons were made by $t$ test or one-way ANOVA using the Newman-Keuls posthoc procedure. Because of the number of comparisons that were made, Bonferroni corrections were made for each questionnaire subscale.

Registry patients were divided into positive and zero nutrient supplementation groups by vitamin classification (ie, fat, water or mineral supplementation). $\chi^{2}$ and $t$ test analysis were also used to examine disease activity using the OMGE, ISQ and QLI scales within the positive and zero supplementation groups. Nutritional intakes were also compared with both IBD diagnosis subgroups (ulcerative colitis and Crohn's disease) using group $t$ test or MannWhitney U procedures. Nutritional intake values were then compared with RDA tables, which are broken down by sex and age group (19 to 24 years, 25 to 50,51 and older), to discover the existence of any intake deficiencies in the nutritional values measured by the questionnaire. A deficiency was defined as a Harvard/Willett computed intake level found to be below the RDA level for that nutrient.

\section{RESULTS}

Observed nutritional intake levels without supplementation for IBD registry patients are listed in Tables 2 to 4 , where the data are separated by sex and age, the same groupings used by the Food and Nutrition Board (16). Results showed that mean intakes for IBD patients were below RDA guidelines for vitamin E, calcium, magnesium, zinc, iodine and selenium. Females were be- 
TABLE 2

Weight, height, protein and fat-soluble vitamin intake without supplementation

\begin{tabular}{lcccccccc}
\hline Category & Age (years) & $\mathrm{n}$ & Weight $(\mathrm{kg})$ & Height $(\mathrm{cm})$ & Protein $(\mathrm{g})$ & Vitamin A $(\mu \mathrm{g} \mathrm{RE})$ & Vitamin D $(\mu \mathrm{g})$ & Vitamin E $(\mathrm{mg} \alpha-\mathrm{TE})$ \\
\hline Males & $19-24$ & 5 & $73.45 \pm 10.07$ & $178.17 \pm 4.34$ & $80.94 \pm 5.83$ & $5593.20 \pm 1508.94$ & $245.66 \pm 126.02$ & $5.46 \pm 0.91$ \\
& $25-50$ & 77 & $81.10 \pm 1.73$ & $179.29 \pm 0.81$ & $64.35 \pm 2.77$ & $7388.42 \pm 796.10$ & $130.70 \pm 12.04$ & $6.83 \pm 0.86$ \\
& $51+$ & 54 & $81.76 \pm 1.75$ & $176.49 \pm 0.99$ & $62.61 \pm 2.44$ & $12.733 .78 \pm 1168.05$ & $160.10 \pm 13.14$ & $6.16 \pm 0.39$ \\
Females & $19-24$ & 8 & $60.57 \pm 5.18$ & $164.04 \pm 2.31$ & $60.19 \pm 8.61$ & $5545.57 \pm 960.67$ & $230.17 \pm 67.69$ & $3.66 \pm 0.56$ \\
& $25-50$ & 101 & $64.38 \pm 1.45$ & $162.99 \pm 0.66$ & $60.38 \pm 1.91$ & $8603.96 \pm 528.65$ & $142.17 \pm 10.01$ & $4.59 \pm 0.27$ \\
& $51+$ & 75 & $66.50 \pm 1.69$ & $161.49 \pm 0.76$ & $53.49 \pm 2.05$ & $10,349.96 \pm 725.58$ & $142.17 \pm 10.07$ & $5.82 \pm 0.75$ \\
\hline
\end{tabular}

All results are presented as mean ( SE. Values in bold text are below recommended dietary allowance guidelines for that group. RE Retinol equivalents; $\alpha$-TE Alphatocopherol equivalents

TABLE 3

Mineral intake levels without supplementation

\begin{tabular}{|c|c|c|c|c|c|c|c|c|c|}
\hline Category & $\begin{array}{c}\text { Age } \\
\text { (years) }\end{array}$ & $\mathrm{n}$ & $\begin{array}{l}\text { Calcium } \\
(\mathrm{mg})\end{array}$ & $\begin{array}{c}\text { Phosphorus } \\
\text { (mg) }\end{array}$ & Magnesium (mg) & $\begin{array}{l}\text { Iron } \\
\text { (mg) }\end{array}$ & $\begin{array}{l}\text { Zinc } \\
\text { (mg) }\end{array}$ & $\begin{array}{l}\text { lodine } \\
(\mu \mathrm{g})\end{array}$ & $\begin{array}{c}\text { Selenium } \\
(\mu \mathrm{g})\end{array}$ \\
\hline \multirow[t]{2}{*}{ Males } & $19-24$ & 5 & $1041.96 \pm 353.26$ & $1401.91 \pm 209.53$ & $261.51 \pm 27.42$ & $10.20 \pm 1.34$ & $12.16 \pm 0.95$ & $17.14 \pm 17.1$ & $1.33 \pm 0.33$ \\
\hline & $25-50$ & 77 & $612.33 \pm 41.39$ & $1064.43 \pm 161.18$ & $215.05 \pm 11.95$ & $10.13 \pm 0.52$ & $10.87 \pm 0.58$ & $41.02 \pm 8.35$ & $1.58 \pm 0.12$ \\
\hline \multirow[t]{2}{*}{ Females } & $19-24$ & 8 & $883.03 \pm 180.56$ & $1140.29 \pm 185.53$ & $212.79 \pm 36.31$ & $12.66 \pm 3.90$ & $11.33 \pm 2.87$ & $9.70 \pm 7.15$ & $1.13 \pm 0.24$ \\
\hline & $25-50$ & 101 & $611.22 \pm 33.94$ & $984.95 \pm 35.68$ & $225.84 \pm 8.96$ & $9.29 \pm 0.46$ & $9.37 \pm 0.34$ & $31.61 \pm 6.15$ & $1.46 \pm 0.09$ \\
\hline
\end{tabular}

All results are presented as mean ( SE. Values in bold text are below recommended dietary allowance guidelines for that group

TABLE 4

Water-soluble vitamin intake without supplementation

\begin{tabular}{lcrlccccc}
\hline Category & Age (years) & \multicolumn{1}{c}{$\mathrm{n}$} & Vitamin C $(\mathrm{mg})$ & Thiamine $(\mathrm{mg})$ & Riboflavin $(\mathrm{mg})$ & Niacin $(\mathrm{mg} \mathrm{NE})$ & Vitamin B6 $(\mathrm{mg})$ & Folate $(\mu \mathrm{g})$ \\
\hline Males & $19-24$ & 5 & $152.67 \pm 38.06$ & $1.17 \pm 0.08$ & $1.83 \pm 0.39$ & $24.60 \pm 5.93$ & $1.82 \pm 0.17$ & $198.88 \pm 19.73$ \\
& $25-50$ & 77 & $140.30 \pm 12.15$ & $1.12 \pm 0.06$ & $1.51 \pm 0.08$ & $35.74 \pm 4.01$ & $1.72 \pm 0.09$ & $221.05 \pm 14.19$ \\
& $51+$ & 54 & $139.09 \pm 11.38$ & $1.20 \pm 0.06$ & $1.63 \pm 0.08$ & $41.34 \pm 5.06$ & $1.96 \pm 0.09$ & $257.64 \pm 13.35$ \\
Females & $19-24$ & 8 & $139.82 \pm 41.21$ & $1.38 \pm 0.31$ & $1.91 \pm 0.39$ & $28.50 \pm 6.24$ & $1.90 \pm 0.44$ & $319.79 \pm 112.22$ \\
& $25-50$ & 101 & $136.81 \pm 9.77$ & $1.02 \pm 0.04$ & $1.44 \pm 0.06$ & $38.13 \pm 3.33$ & $1.65 \pm 0.06$ & $213.82 \pm 9.54$ \\
& $51+$ & 75 & $119.29 \pm 9.68$ & $1.01 \pm 0.05$ & $1.43 \pm 0.07$ & $35.33 \pm 3.60$ & $1.68 \pm 0.08$ & $222.41 \pm 12.7$ \\
\hline
\end{tabular}

All results are presented as mean ( SE. Values in bold text are below recommended dietary allowance guidelines for that group. NE Niacin equivalents

low RDA guidelines for iron while men were below for vitamin B6. There were also some deficiencies according to age in males. Younger men (ages 19 to 50) were deficient in thiamine, riboflavin (ages 25 to 50) and folate (ages 19 to 24), and older men (ages 51 and older) were deficient in protein. Only two deficiencies were seen by age group in women: thiamine (ages 25 to 50) and phosphorus (ages 19 to 24). There were no deficiencies by sex or age for vitamins $\mathrm{A}, \mathrm{C}, \mathrm{D}$ and niacin.

There were no observed nutrient intake differences between the ulcerative colitis and Crohn's disease groups. No differences in disease activity as measured by OMGE or quality of life as measured by the QLI were found in relation to adequate intakes versus intake defi- ciencies (according to RDA guidelines). Tables 5 and 6 present the disease activity data according to OMGE subcategories and quality of life data as measured by the QLI.

The positive mineral supplementation group showed a significant decrease in quality of life as measured by the QLI $(t=3.54, \mathrm{P}<0.001)$ and the systemic symptom subscale of the ISQ $(t=2.19, P=0.029)$. A more detailed examination of these scales revealed patient-reported decreases in quality of life in the following areas: activities $\left(\chi^{2}=5.25, \quad \mathrm{P}=0.022\right), \quad$ abscess $\quad\left(\chi^{2}=\right.$ 10.28, $\mathrm{P}=0.0013)$, fever higher than 37.8 $\mathrm{C}\left(\chi^{2}=4.36, \mathrm{P}=0.037\right)$ and $\mathrm{ab}$ dominal pain $\left(\chi^{2}=10.91, \mathrm{P}=0.012\right)$.

Correlational analysis of mineral intakes with mineral serum levels shows low correlations with calcium $(\mathrm{r}=-0.0072, \mathrm{n}=122)$, iron $(\mathrm{r}=-0.0315$, $n=9)$, phosphorous $(r=0.0565, n=122)$, magnesium $(r=0.0145, n=40)$ and potassium $(r=-0.0279, n=129)$. However, a significant correlation for zinc ( $r=0.6798, n=12, \mathrm{P}<0.05$ ) was observed. Low correlations were also noted for other nutrients including protein $(r=0.0796, n=122)$ and vitamin $B_{12}$ $(\mathrm{r}=0.0275, \mathrm{n}=9)$.

There were also no significant differences noted in nutrient blood levels by diagnosis group. However, it is interesting to note that, except for iron and sodium, Crohn's disease patients had lower blood levels of all other nutrients (Tables 5,6). Within recognized limitations, some of the results imply that a prospective, controlled study of blood 
TABLE 5

Disease activity and quality of life responses and number of patients (Organisation Mondiale de Gastroentérologie Index)

\begin{tabular}{|c|c|c|}
\hline General well-being & & 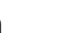 \\
\hline Excellent & & 5 \\
\hline Very good & & 9 \\
\hline Good & & 0 \\
\hline Fair & & 6 \\
\hline Poor & & 0 \\
\hline Abdominal pain & & 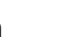 \\
\hline None & & 1 \\
\hline Mild & & 5 \\
\hline Moderate & & 7 \\
\hline Severe & & 7 \\
\hline Abdominal mass & & 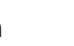 \\
\hline None & & 3 \\
\hline Questionable & & 9 \\
\hline Definite & & 5 \\
\hline Definite and tender & & 3 \\
\hline Number of liquid stools & & 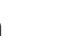 \\
\hline $0-2$ & & 4 \\
\hline $3-4$ & & 5 \\
\hline $5-6$ & & 3 \\
\hline $7-8$ & & 2 \\
\hline $9-10$ & & 0 \\
\hline $11+$ & & 6 \\
\hline Complications & Yes & No \\
\hline Pain in joints & 151 & 169 \\
\hline Eye inflammation & 48 & 272 \\
\hline Acute skin disease & 42 & 278 \\
\hline Evolving skin ulcer & 2 & 318 \\
\hline Ulcers in mouth & 41 & 279 \\
\hline Anal fissure & 37 & 283 \\
\hline New fistula & 9 & 311 \\
\hline Abscess & 8 & 312 \\
\hline Fever higher than $37.8 \supset \mathrm{C}$ & 23 & 297 \\
\hline
\end{tabular}

TABLE 6

Disease activity and quality of life responses and number of patients (Quality of Life index )

\begin{tabular}{lccc}
\hline & Impaired & $\begin{array}{c}\text { Moderately } \\
\text { impaired }\end{array}$ & $\begin{array}{c}\text { Not } \\
\text { impaired }\end{array}$ \\
\hline Activity & 16 & 18 & 286 \\
Daily & 4 & 12 & 304 \\
$\quad$ living & & & \\
Health & 13 & 91 & 216 \\
Support & 4 & 24 & 292 \\
Outlook & 3 & 68 & 249 \\
\hline
\end{tabular}

TABLE 7

Blood nutrient level by ulcerative colitis and Crohn's disease diagnosis groups

\begin{tabular}{|c|c|c|c|c|}
\hline Nutrient & Diagnosis & $\mathrm{n}$ & Mean / SD & P value \\
\hline \multirow[t]{2}{*}{ Calcium (mmol/L) } & Crohn's disease & 81 & $2.27 \pm 0.25$ & 0.871 \\
\hline & Ulcerative colitis & 42 & $2.27 \pm 0.18$ & \\
\hline \multirow[t]{2}{*}{ Phosphorus (mmol/L) } & Crohn's disease & 80 & $1.16 \pm 0.22$ & 0.556 \\
\hline & Ulcerative colitis & 42 & $1.19 \pm 0.30$ & \\
\hline \multirow[t]{2}{*}{ Magnesium (mmol/L) } & Crohn's disease & 22 & $0.83 \pm 0.349$ & 0.624 \\
\hline & Ulcerative colitis & 18 & $0.85 \pm 0.116$ & \\
\hline \multirow[t]{2}{*}{ Iron ( $\mu \mathrm{mol} / \mathrm{L})$} & Crohn's disease & 4 & $12.40 \pm 10.35$ & $0.462^{*}$ \\
\hline & Ulcerative colitis & 5 & $7.37 \pm 5.27$ & \\
\hline \multirow[t]{2}{*}{ Zinc $(\mu \mathrm{mol} / \mathrm{L})$} & Crohn's disease & 6 & $11.09 \pm 2.26$ & $0.871^{*}$ \\
\hline & Ulcerative colitis & 6 & $11.35 \pm 2.08$ & \\
\hline \multirow[t]{2}{*}{ Potassium (mEq/L) } & Crohn's disease & 85 & $4.06 \pm 0.35$ & 0.076 \\
\hline & Ulcerative colitis & 44 & $4.18 \pm 0.34$ & \\
\hline \multirow[t]{2}{*}{ Copper $(\mu \mathrm{mol} / \mathrm{L})$} & Crohn's disease & 5 & $11.33 \pm 6.36$ & $0.549^{*}$ \\
\hline & Ulcerative colitis & 3 & $13.90 \pm 1.64$ & \\
\hline \multirow[t]{2}{*}{ Protein (g/L) } & Crohn's disease & 80 & $63.76 \pm 8.69$ & 0.977 \\
\hline & Ulcerative colitis & 42 & $63.81 \pm 7.85$ & \\
\hline \multirow[t]{2}{*}{ Sodium (mEq/L) } & Crohn's disease & 85 & $141.6 \pm 2.96$ & 0.180 \\
\hline & Ulcerative colitis & 44 & $140.8 \pm 3.40$ & \\
\hline \multirow[t]{2}{*}{ Vitamin $B_{12}(\mathrm{pg} / \mathrm{mL})$} & Crohn's disease & 5 & $477.2 \pm 283.1$ & $0.221^{*}$ \\
\hline & Ulcerative colitis & 4 & $791.0 \pm 484.9$ & \\
\hline
\end{tabular}

*Mann-Whitney U test statistic, all others are $t$ tests

levels, concurrent with measurement of intake levels, would be a possible next step.

Patients who received fat-soluble vitamins (160 of $320,50.0 \%$ ) or vitamin B (181 of $320,56.6 \%)$ supplementation showed a significant decrease in quality of life as measured by the QLI $(t=2.01, P=0.045$ and $t=2.15, P=0.032$, respectively). QLI subscale analysis showed no group differences in activities, daily living, support or outlook. However, fat-soluble vitamin and vitamin B supplemented patients were more likely to rate their health as poor compared with the nonsupplemented group $\left(\chi^{2}=6.895, \quad \mathrm{P}=0.009\right.$ and $\chi^{2}=4.881$, $\mathrm{P}=0.027$, respectively). Feelings of poor health included: lack of energy, not feeling 'up to par', and feeling very ill, weak and washed out most of the time.

There were no significant differences noted on the OMGE, ISQ or QLI scales by patient diagnosis group (ulcerative colitis or Crohn's disease). No overall significances were observed between nutrient intake and disease activity as measured by OMGE or quality of life as measured by the QLI. This prompted an investigation of nutrient intake by subscale of each of these measures. OMGE revealed several significances although few passed Bonferroni corrections. High intake levels of manganese $(\mathrm{P}<0.0047)$ were noted with abdominal mass (OMGE subscale), and high levels of $\mathrm{B}_{6}$ and iron showed significance for abdominal mass, even after Bonferroni adjustment $(\mathrm{P}<0.0006$ and $\mathrm{P}<0.0003$, respectively). High intake levels of zinc and $\mathrm{B}_{6}$ intake were also significant for severe abdominal pain (OMGE subscale) (both $\mathrm{P}<0.0005$ ).

Similar results were also found in the QLI data for iron, zinc, vitamin $\mathrm{B}_{6}$, iodine and selenium. ANOVA results showed that high intake levels of iron were associated with poor reports in activities of daily living $(\mathrm{P}=0.0006)$, poor health $\quad(\mathrm{P}=0.0072), \quad$ support $(\mathrm{P}=0.0016)$ and patient outlook $(\mathrm{P}<0.0004)$. High levels of zinc were similarly significant with poor health $(\mathrm{P}=0.022)$. High levels of vitamin $\mathrm{B}_{6}$ were significant with low levels of activities $(\mathrm{P}=0.0041)$, poor health $(\mathrm{P}<0.0001)$, low activities of daily living $\quad(\mathrm{P}<0.0001)$, poor support 
$(\mathrm{P}=0.0015)$ and poor outlook $(\mathrm{P}=0.0001)$. Iodine showed similar results with high intake levels associated with low activities $(\mathrm{P}=0.0066)$, poor activities of daily living ( $\mathrm{P}=0.0022)$, poor health $(\mathrm{P}<0.0001)$ and poor outlook $(\mathrm{P}=0.0111)$. High selenium intake was also significantly associated with poor health $(\mathrm{P}=0.0003)$. The low numbers of patients in the severest categories must be considered when interpreting these results (Tables 5,6).

\section{DISCUSSION}

The H/WSQFFQ is a useful tool for assessment of the nutritional status of the IBD patient. The questionnaire not only provides valuable measurement data to the clinician, but also helps the patient remain aware that nutritional problems are associated with IBD.

Results showed that mean intake levels for IBD patients were below RDA guidelines in all age and sex groups for several nutrients. Females were below RDA guidelines for iron while men were below for vitamin $\mathrm{B}_{6}$. There were also some deficiencies according to age in males and two deficiencies were seen by age group in women. Regardless of diagnosis, IBD patients generally are below RDA recommendations for nutritional intake. While there were significant differences between nutrient intake as measured by quality of life and disease activity subscales, the low numbers of patients in the most severe and poor categories of the OMGE subscales for abdominal pain and abdominal mass could have been a problem with this analysis (Table 5,6). For the vast majority of categories no differences were seen.

The results of this study suggest that vitamin supplementation may not be effective in improving the nutritional status of the IBD patient. The reason may be that, because of the malabsorption problems of the IBD patient, oral supplementation may not sufficiently increase nutrient levels in the blood.
Also, the patient who feels worse might be receiving supplementation from the physician or may be independently taking supplements, both in an effort to feel better. It is clear that relationships are complex; however, the instrumentation reports that these patients are feeling worse, despite supplementation.

In the chart review it was interesting to note that only 10 of the 130 patients $(7.7 \%)$ received a nutritional consultation as part of IBD treatment. Intakes, as measured by the H/WSQFFQ, were generally not correlated with blood levels, except for zinc. Crohn's patients had lower blood levels of all nutrients except iron and sodium ( $\mathrm{Ta}$ ble 7). There are various factors affecting serum levels and nutrient intake levels, and physicians need to be reminded of the nutritional problems inherent in IBD. Simply prescribing a diet high in nutrients may not provide the patient with the proper levels of the nutrients previously mentioned. Monitoring the intake levels of these nutrients may not provide a reliable indicator of how much of the nutrient is proceeding into the system, and severe nutritional deficiencies may be best treated by diet combined with other approaches.

ACKNOWLEDGEMENTS: This research was made possible by a grant from the Dorothy Rider Pool Health Care Trust Fund.

\section{REFERENCES}

1. Clark ML. Nutrition in inflammatory bowel disease. Can J Gastroenterol 1988;2(Suppl A):18-20.

2. Love AHG, Metabolic response to nutrition. Can J Gastroenterol 1988;2(Suppl A):21-4.

3. Driscoll RH, Rosenberg IH. Total parenteral nutrition in inflammatory bowel disease. Med Clin North Am 1978;62:185-201.

4. Giaffer MH, Cann P, Holdsworth CD. Long-term effects of elemental and exclusion diets for Crohn's disease.
Aliment Pharmacol Ther 1991;5:115-25.

5. Teahon K, Smethurst P, Pearson M, Levi AJ, Bjarnason I. The effect of elemental diet on intestinal permeability and inflammation in Crohn's disease. Gastroenterology 1991;101:84-9.

6. Lennard-Jones JE. Nutrition in Crohn's disease. Ann R Coll Surg Engl 1990;72:152-4.

7. Cravo M, Camilo ME, Pinto Correia J. Nutritional support in Crohn's disease: Which route? Am J Gastroenterol 1991;86:317-21.

8. Reed JF, Moser KA, Faust LA, Mills S. Data management of an inflammatory bowel disease registry. J Med Syst 1992;16:113-27.

9. Reed JF, Faust LA. An analysis of Crohn's disease activity indices from a registry of patients in Eastern Pennsylvania. Can J Gastroenterol 1991;5:199-208.

10. Willett WC, Sampson L, Stampfer MJ, et al. Reproducibility and validity of a semi-quantitative food frequency questionnaire. Am J Epidemiol 1985;122:51-65.

11. Colditz GA, Willett WC, Stampfer MJ, Rosner B, Hennekens CH, Speizer FE. The influence of age, relative weight, smoking, and alcohol intake on the reproducibility of a dietary questionnaire. Int J Epidemiol 1987;16:392-8.

12. Willett WC, Reynolds RO, Cottrell-Hoehner S, Sampson L, Browne ML. Comparison of a semi-quantitative food frequency questionnaire with a one year diet record. J Am Diet Assoc 1987;87:43-7.

13. Willett WC, Sampson L, Browne ML, et al. The use of a self-administered questionnaire to assess diet four years in the past. Am J Epidemiol 1988;127:188-99.

14. Willett WC, Stampfer MJ. Total energy intake implications for epidemiologic analyses. Am J Epidemiol 1986;124:17-27.

15. Salvini S, Hunter DJ, Sampson L, et al. Food-based validation of a dietary questionnaire: the effects of week-to-week variation in food consumption. Int J Epidemiol 1989;18:858-67.

16. Food and Nutrition Board, National Academy of Sciences-National Research Council. Recommended Dietary Allowances, 10th edn. Washington: National Academy Press, 1989. 


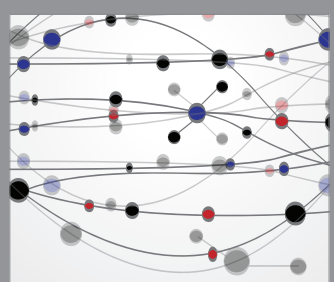

The Scientific World Journal
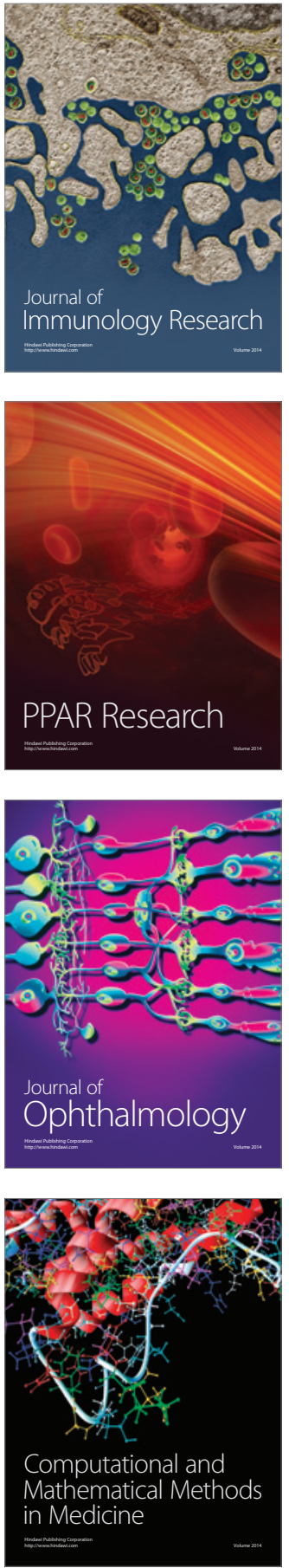

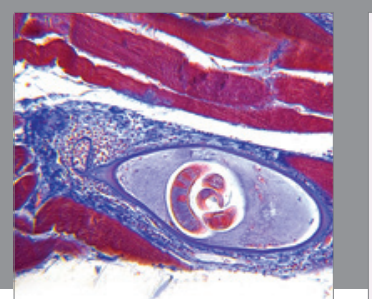

Gastroenterology Research and Practice

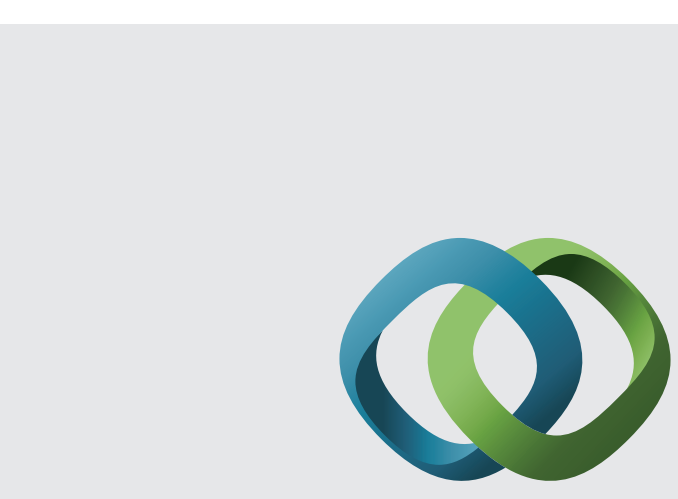

\section{Hindawi}

Submit your manuscripts at

http://www.hindawi.com
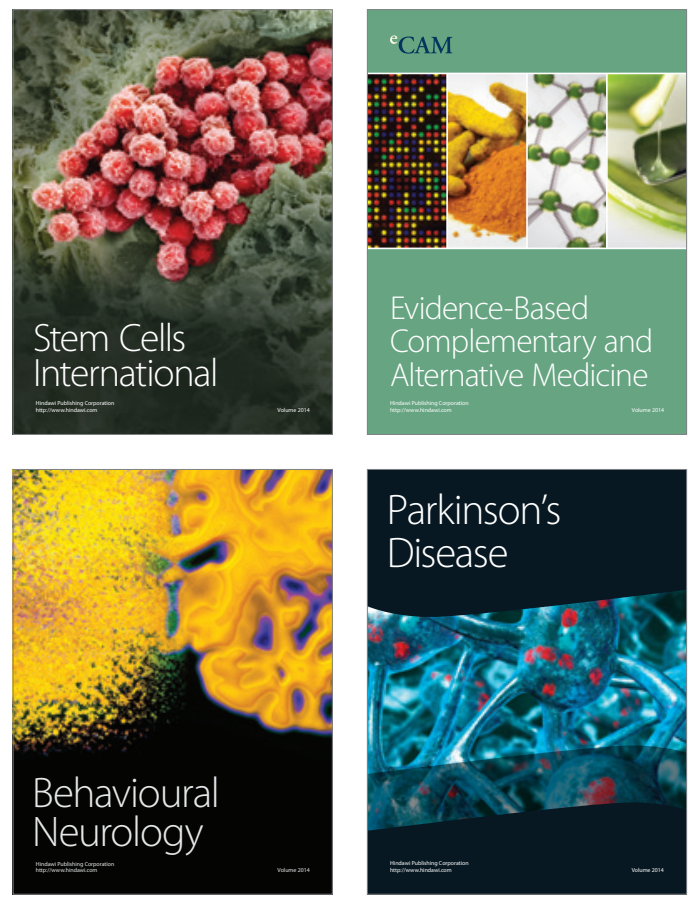
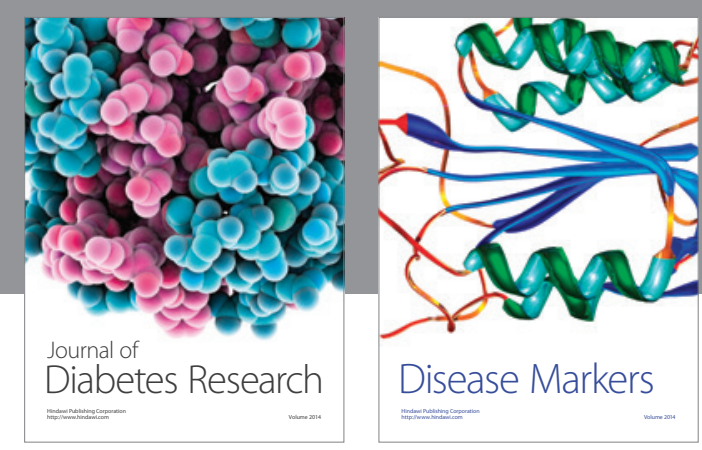

Disease Markers
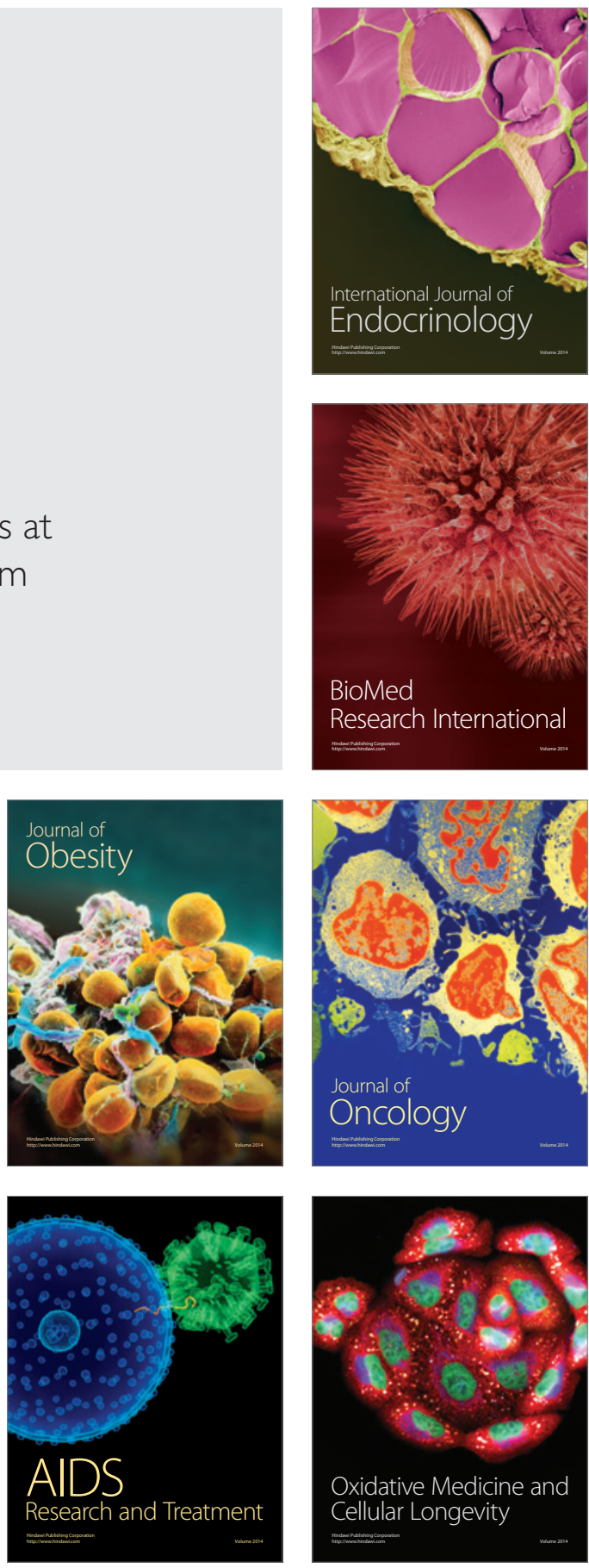